\title{
探析水利工程建设中的软土地基处理施工质量管理
}

\author{
赵韬 \\ 新疆塔里木河流域巴音郭楞管理局开都一孔雀河管理处孔雀河上游管理站 \\ DOI:10.32629/btr.v3i6.3166
}

\begin{abstract}
[摘 要] 现阶段, 经济不断的发展,科学技术也随之不断的发展, 人们对于生活要求越来越高,为了满足人 们的需求,水利工程建设就要不断的增加,而目前水利工程基本上都是在软土地基中进行建设,施工质量 极易出现问题。因此,本文对软土地基的特点进行分析,并分析了其有何处理技术。
\end{abstract}

[关键词] 水利工程建设中; 软土地基; 处理技术; 施工质量

由于水利工程建设具有较为复杂的 环境, 而水利工程建设的质量与地基有 着直接地关系, 而目前大多数的工程都 是软土地基, 而面临软土地基, 施工难度 便大大提高了, 然而地基一旦没有处理 良好, 直接会影响整个工程建设。因此, 本文分析了软土地基有何种特点, 并对 其处理技术进行了分析。

\section{1 简述软土地基}

软土地基主要由粉土以及粘土等细 微颗粒含量多的松软土、具有较大孔隙 的机质土, 另外还有松散的沙以及泥炭 等构成的土层, 具有较高的地下水位, 以 及不够稳定的构造物, 所以, 沉降情况特 别容易发生。软土地基在水利工程建设 中比较普遍, 若是施工时有问题存在或 者对其重视度不高, 对建筑完整程度有 极大的影响, 甚至破坏建筑。因此, 对于 软土地基的各种问题都要注意, 从软土 地基的特点入手进行了解, 根据软土地 基的实际情况选择相应的技术方法, 保 证软土地基处理施工质量, 以此保证工 程质量。

\section{2 软土地基有何特点}

软土地基不稳定, 压缩性较高, 和普 通土质相比具有较高的含水量, 以及较 小的容量, 因此孔隙较大, 在进行压缩的 时候, 比较平缓, 然而当软土地基压力比 规定的高的时候, 下降的情况就会出现, 极大可能会有突然下降的现象发生。同 时, 软土的灵敏度也比较高, 是沉积物的 存在, 絮凝状结构是其主要形态, 若是原
状土是软土的情况, 具有较高的结构强 度, 一旦被搅动或者是遭到破坏, 结构 就会损坏, 其强度下降也会特别明显, 以至于出现稀释的现象。另外, 软土透 水性极其不好, 透水率在垂直层面上很 低, 由于具有较长时间的结构物沉降, 加荷时, 就会增大孔隙水压力, 从而明 显降低地基强度, 极大影响到排水固结 的施工环节 ${ }^{[1]}$ 。

\section{3 为保证施工质量,有何软土} 地基处理技术

在水利工程建设中, 其质量与软土 地基的质量有着直接的关系, 因此, 要根 据工程的实际情况来选择软土地基的施 工技术, 以此保证工程的质量。软土地基 的淤泥越多, 深层处理就越困难。在此期 间, 可以选择桩基础方法。在传统的桩基 础方法中, 木桩和砂石桩是最常用的方 法, 但是, 随着科学技术的不断发展, 工 具的数量不断增加, 目前, 水利工程建设 中广泛应用钢筋混凝土预制桩, 并得到 高度重视。在施工过程中, 成孔方式会利 用人工作用或者是机器来进行, 再将混 凝土浇筑软土地基内, 混凝土在交换离 子或者是释放热量的后, 会改变桩基周 围的软土特性。在此期间, 基础的强度得 到了显着提高, 并且生产出了防止沉降 的复合基础。除此之外, 因为混凝土具有 较高的承载力, 因此, 相对易于操作, 且 具有较低的成本, 可以将工程稳定性大 大提高, 钢筋混凝土预制桩的应用将稳 定效果以及抗压能力显著提升, 以此保
证施工质量 ${ }^{[2]}$ 。

在进行基础工程之前, 运用加载预 压法, 软土地基处理要依照预压负载措 施进行, 将地基强度进行强化, 之后再进 行施工建造工作。在完工之后, 若是软土 地基无任何变化, 具有较强承载力, 就可 在自重的基础上将预压负载落实。作业 区域中软土地基若是具有较差的透水性, 俄国想将较差排水距离产生有效的避免, 就要将土体进行固结, 并且在地基土层 中要将坚向排水通道挖出, 以此保证软 土地基的质量 ${ }^{[3]}$ 。

对于软土地基处理上, 换填法是一 种常见的措施, 勘察施工区域的土质, 选 择符合其土质需求的土壤, 然后将原有 的软土替换掉, 以此保证地基能够满足 建设需求。在进行填土法的过程中, 首先 就是将不符合标准的软土挖出来, 再将 选择合适的土质填入, 之后进行夯实, 这 样就可以保证水利工程正常开展。通常 情况下, 我卵石、碎石、以及粗砂是主要 的换填土质, 填充方式要分层进行, 以此 将整体的稳定性和安全性进行保障。矿 渣碎石是最先填入的, 这样的话会明显 提升地基透水性, 以此保证地基基础; 其 次是灰土层, 这是为了给地基平衡受力 提供保障, 将地基的稳定性持续增强; 砂 垫层是最后一层, 因为淤泥中会存在一 些气体以及水分, 而砂垫层的作用就是 将这些气体以及水分去掉, 将地基土质 固结并且降低及承载力提升。在施工开 始之前, 技术人员选择填入物时, 要依照 


\title{
解析建筑工程管理模式现状及创新发展
}

\author{
于兴会 \\ 内蒙古自治区赤峰市喀喇沁旗住房和城乡建设局 \\ DOI:10.32629/btr.v3i6.3167
}

\begin{abstract}
[摘要] 现阶段,我国建筑行业发展水平显著提高,建筑工程管理模式也日益完善,但是工程管理模式依 然存在明显的不足,阻碍了建筑行业的健康发展。因此,有必要深入分析、正确认识建筑工程管理中存在 问题,并采取科学有效的应对措施,促进建筑工程管理模式的创新发展。
\end{abstract}

[关键词] 建筑工程; 管理模式; 创新发展

当前, 建筑行业发展势头正猛, 但是 工程管理模式依然需要不断调整和完善, 传统落后的工程管理模式对建筑行业发 展产生了一定的阻碍作用。建筑单位需 结合实际, 改进工程管理模式, 推动工程 管理模式的创新, 为建筑工程的顺利竣 工提供助力。

\section{的意义}

1 建筑工程管理模式创新发展

现阶段, 我国国内基础设施建设情 况日益改善, 政府也投入了大量的人力 和物力, 城市化建设取得了阶段性成果。 但是市场对建筑工程的施工要求也明显 提高, 需要建筑单位创新工程管理模式, 改进管理质量, 增大工程的综合效益。又 由于建筑行业能耗较大, 污染较多, 为实 现建筑行业的可持续发展, 应当积极转 变管理模式, 坚持可持续发展道路, 促使 建筑工程向绿色化转型。

\section{2 建筑工程管理现状}

2.1人才数量明显不足

建筑工程施工人员多为农民工, 其 综合素质较低, 尚未接受系统的技术培
训。因此无法应对紧急状况, 加大了工 程建设的安全隐患。且建筑工程施工中, 人才短缺较为常见, 出现上述现象主要 与劳动力需求量大, 福利待遇差有关。 如此, 就降低了年轻人对建筑施工的兴 趣, 专业人才数量有限。工程师专业知 识的欠缺无法保证设备的正常运行, 设 备无法发挥其作用, 不利于工程的顺利 开展。

2. 2 建筑工程管理机制滞后

建筑工程管理中, 管理体系建设相 对滞后, 建筑单位经常忽视管理工作。部 分建筑工程企业为降低成本投入, 未设 立管理部门, 由其他部门承担管理职责, 因此影响了管理工作的效率, 容易出现 管理职责缺失或职责重叠等问题, 进而 引发较为严重的工程安全隐患, 对建筑 工程施工质量产生较大的影响。而出现 突发状况后, 由于相关机制的不健全, 无 法采取切实有效的处理措施, 进而引发 严重的工程质量问题, 延缓了工程进度, 威胁了人员安全。

2. 3管理方法不够先进
建筑工程管理中, 部分管理人员未 按照要求开展实地勘察, 仅依据理论制 定工程计划, 降低了工程施工质量。再 者, 工程施工中容易受到环境、气候和 人为因素的影响, 使实际的施工进度与 施工进度计划存在明显的误差。另外, 部分管理人员依旧采用传统的方式制 定施工进度计划, 不重视现代科技的发 展与应用, 同样不利于改善管理水平。 上述情况导致我国建筑工程管理水平 较低, 缺乏竞争力, 无法顺应国际化发 展需求。设计单位在设计工作中应高度 重视建筑和机电设计, 但是机电结构复 杂性较强, 无法实现设计总体承包机制, 再加上我国建筑工程监督管理技术存 在明显不足, 管理不力, 最终直接影响 到了工程质量。

\section{3 创新建筑工程管理的有效} 对策

3. 1 积极创新组织机构

传统建筑工程管理中, 项目经理十 分关键, 其在工程管理中发挥了重要作 用, 项目经理需要在工程项目施工中科
实际情况进行, 会更加稳定地基, 保证地 基质量 ${ }^{[4]}$ 。

\section{4 结束语}

总之, 水利工程建设时, 工程整体质 量都受制于软土地基施工质量, 所以, 若 想将工程需求满足, 软土地基就要正确 的处理, 在施工过程中, 有很多处理软土 地基的方式, 所以, 要根据工程实际的情
况来选择如何处理软土地基的方式, 选 取的软土地基技术合理的话, 可以有效 保证水利工程施工质量。

\section{[参考文献]}

[1]王瑞博. 关于建筑地基工程建设 中软土地基处理的探析 [J]. 中国室内装 饰装修天地,2017,(21):95.

[2] 解银全, 李超.水利工程施工
中软土地基处理技术探析 [J]. 居 舍,2018,(15):42.

[3]纪春峰.探析建筑地基工程建设 的软土地基处理及其质量管理 [J]. 建材 与装饰,2017,(25):92-93.

[4]范中斌.探析水利工程施工中软 土地基处理技术 [J]. 建筑技术研 究,2019,2(5):161-162. 